\title{
繊維および糸におけるエロージョンの測定と評価法*
}

\author{
鮑 力 民*1, 銭 丹 娜*2, 佐 藤 康 $2^{* 2}$, 島川 聡*3 \\ 高寺政行*1, 日向 滋*4, 剣持 潔*1
}

\section{Measurement and Evaluation of Erosion Characteristic for Fiber and Yarn}

Limin BAO*5, Danna QIAN, Yasuyuki SATO, Satoshi SHIMAKAWA, Masayuki TAKATERA, Shigeru HINATA and Kiyoshi KEMMOCHI

\footnotetext{
${ }^{* 5}$ Faculty of Textile Science and Technology, Shinshu University,
} 3-15-1 Tokida, Ueda-shi, Nagano, 386-8567 Japan

\begin{abstract}
Bag-filter of fibrous components is widely used as materials that clean exhaust gas. It is reported that the filter damage phenomenon at dust collection is a destruction of erosion wear caused by the particle collision. So, we are necessary to determine the life prediction of bag-filter. It is required to clear up erosion mechanism of fibrous materials. The experiment and an evaluation method were developed to investigate an erosion characteristic of fiber. Using the experiment, erosion of fiber materials was able to be reproduced. Relation between erosion damage rate of a sample and total kinetic energy of particles before colliding by measurement displays a characteristic of erosion in fiber materials. Using suggested damage energy curve, we can evaluate an erosion wear characteristic of fibers in a different experiment condition. An erosion characteristic of mixed yarn and FRP is estimated using this method.
\end{abstract}

Key Words : Erosion, Solid Particle Impact, Wear, Fiber, Yarn, Measurement and Evaluation of Erosion

\section{1. 緒言}

環境問題が重視されている今日では,クリーンな地 球環境を保つために，ごみ焼却施設では諸装置の性能 向上のほかに, 運転上の安全を確保する設計が重要な 役割を占めている．現在，ごみ焼却炉から出た粉じん を含む有害ガス，ダイオキシンおよび重金属などを高 効率で除去できる方法として繊維材料で構成されてい るバグフィルタが広く用いられている．また，バグフ イルタは, 粒子状物質に吸着したダイオキシン類など 環境污染物質の除去性能が高く評価されたため, 都市 ごみ焼却設備だけでなく産業廃棄物焼却設備を始め, 多くの排ガス処理システムに使用されている(1). しか し，長期間使われることや内部の偏流などの不正使用 により損傷し，有毒な気体が外部へ流れることにより 周辺地域の環境を污染する問題が生じている. バグフィル夕損傷の原因は化学反応および高温によ

* 原稿受付 2007 年 5 月 16 日.

*1 正員, 信州大学緉維学部 (ङ386-8567 上田市常田 3-15-1).

*2 信州大学大学院工学系研究科( $\mathbb{E} 386-8567$ 上田市常田 315-1).

*3 正員, 信州大学大学院総合工学系研究科

*4 正員, フェロー, 信州大学瀻維学部.

E-mail : baolimi@shinshu-u.ac.jp
る材料の劣化などが指摘されているが，その一つは, 排ガスに含まれている粒子の衝突による摩耗損傷 (ド ライサンド・エロージョン)との実験調査結果が報告 されている(2).

構造材料のエロージョンの研究は橋本ら(3)(4)による 長年にわたる金属と無機材料を主とした基礎研究か ら，多くの成果が得られている，その応用により，産 業界に多く貢献している。一方繊維材料とその構造材 料の摩耗では古くから軍服, 鉱山のベルトの摩耗が注 目されて, 摩耗の研究が始まると同時に, 盛んに調查 されている. Galbraith は繊維の摩耗を直接摩耗(繊 維と滑っている硬い表面)，アブレシブ摩耗と間接摩 耗(繊維と繊維との間)に分けて, その研究結果を詳し くまとめた ${ }^{(5)}$.また, 最近, 繊維強化複合材料のドラ イサンド・エロージョンについて工業界の要望で活発 に研究されている. 1986 年から材料のエロージョン 性能の研究は, $\mathrm{Pool}^{(6)}$ により金属からポリマとその複 合物まで及んだ。その後, Harsha ら(7)や Barkoula ら (8)を代表として，工業用として多く使われている GFRP, CFRP などに対して, 衝撃角度, 速度と衝撃 粒子の形状の影響, 母材樹脂の耐エロージョン性の調 查などを行った. FRPの研究は繊維材料のエロージ ヨンメカニズムが不明なので, おもに実験的な考察に 
止まっている．繊維材料と繊維集合体(系とフィラメ ント)のエロージョンのメカニズムの究明も繊維強化 複合材料のエロージョン特性の向上につながると考え ている.しかし, 繊維材料と繊維集合体のエロージョ ンの研究は見当たらず, 不明の点が多くあった.

本研究では纎維材料と繊維集合体のエロージョンに 注目し, その実験方法と評価方法を考案し, 考案され た測定装置を試作する。 それを利用して繊維とその集 合体のエロージョンを再現し, 繊維材料とその集合体 のエロージョン特性の測定と評価を試みる.

\section{2. エロージョンの測定方法}

\section{$2 \cdot 1$ 緎維材料のエロージョン試験 金属材料等} の板材のエロージョン特性を調べるためには, 一定の 条件で粉体を板材に衝突させ, 試料を摩耗させ, 実験 前後の材料の重量差を摩耗量として測定し, その摩耗 量より材料のエロージョン特性を評価している(3)(4). しかし, 繊維材料では同様の方法で測定するのは困難 である. 繊維材料は金属ブロックに比べ，はるかに小 さいので実験前後の重量差がわずかである. また, 温 度と湿度による影響が大きく, 実験中の人間の触りに より大きな誤差が生じる.さらに瀻維のすきまに粒子 が入り込んでしまう。 そのため繊維だけの正確な変化 量がわからず, 誤差が出やすくなるのである.よって 繊維材料に対しては今までと違った実験方法が必要だ と考える.

本研究では次のように繊維のドライサンド・エロー ジョン実験方法を提案する.

長繊維または繊維で構成された糸に，一定の粒径分 布の粉体を一定の衝突角度で高速に衝突させ, 緎維を

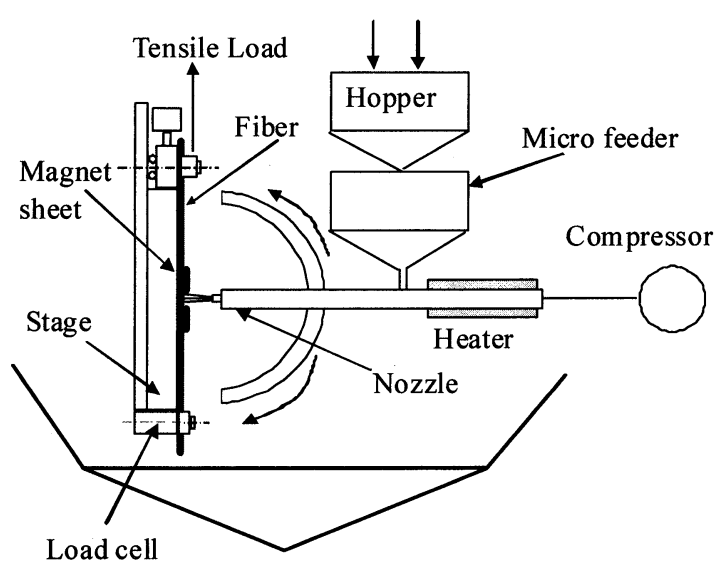

Fig. 1 Schematic drawing of the test system for erosion of fibers
摩耗させる。一定時間の摩耗後, 摩耗された糸の引張 試験を行い, その強度と伸長を測定する. 繊維強度の 低下の測定により，繊維のドライサンド・エロージョ ン状況を推測し, 繊維における摩耗特性の評価を行 う.

図 1 は提案された実験装置の概要図である。図 2 は その写真である。長纎維または糸のサンプルの両端を ロードセル(LUB-B 100 N, KYOWA Co. Ltd.) と電 動スライダに付けたチャックに固定する. 繊維をたる まないようにステージの上に置く，噴流により繊維が ステージの上に振動しているので, 繊維の振動範囲は 粒子衝突範囲を超えないように繊維の両端にマグネッ トシートで固定する。マグネットシート間の距離は $15 \mathrm{~mm}$ であるサンプルから一定の距離離れたエアガ ンの噴射口から毎秒一定量の粉体を発射させ, サンプ ルに衝突させる．粉体と繊維の衝突角度はスライダに より $15^{\circ} \sim 90^{\circ}$ 変化できる.また粉体はマイクロフィ ーダ(ME-1, TSUTSUI RIKAGAKU KIKAI Co. Ltd.)により一定量をエアガンに供給する，粉体が緎 維と衝突してから, 一定の時間経過後, マグネットシ ートを外し, 摩耗により損傷している繊維または糸を 電動スライダで破断するまで引っ張り, その変位-荷 重の関係と破断力をロードセルにより計測し，データ 収集システム (PCD-100, KYOWA Co. Ltd.)に記録 する.

エアガンのノズルから流出したすぐ後の噴流中央部 の速度分布は一様で，ポテンシャルコア部分を超える と均一な噴流速度部分が少なくなり, サンプル瀻維の 直径方向にあたる部分の速度分布は不均一になり，工 ロージョンの不均一が生じる、コア部分が小さくなる と, サンプルをセットしにくくなる.ここで，ノズル からサンプルまでの距離を変化させ，ピト一管流速計

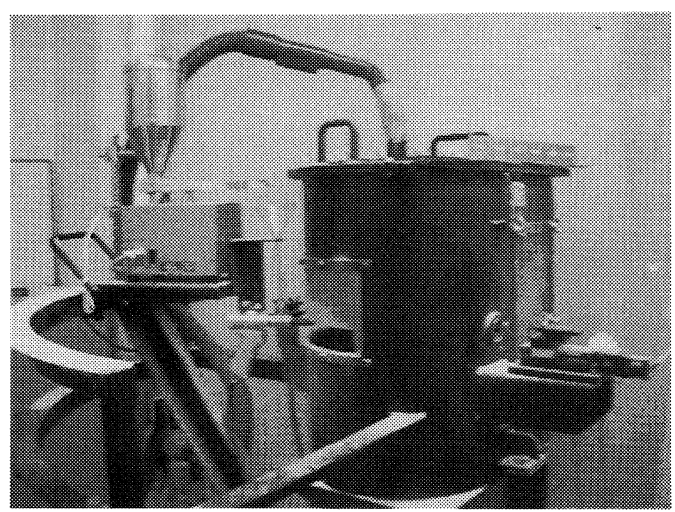

Fig. 2 Photograph of experimental apparatus 
を利用してその速度の分布を測定した，図 3 はその測 定結果である. 図 3 に示したように, ノズル内径が $5.35 \mathrm{~mm}$ であると, $15 \mathrm{~mm}$ 以下離れた場合, 約 $4 \mathrm{~mm}$ の幅で一様速度分布のコアがあるから, 本研究では, 衝突距離は $10 \mathrm{~mm}$ に設けた。

本実験装置では, ノズル内径は $5.35 \mathrm{~mm}$ で, エア コンプレッサとノズルの間に設けるエアタンク (60 リ ットル)の圧力の制御で粉体の噴射速度を調節する. 図 4 は測定したエアタンクの圧力と噴射速度の関係で ある。なお粉体供給量を一定にするために実験環境は 温度 $20^{\circ} \mathrm{C} \pm 1^{\circ} \mathrm{C}$, 湿度 $65 \% \pm 5 \%$ とした恒温恒湿室で 行った。

$2 \cdot 2$ 試料 試料は, 東洋紡製の Procon 緎維, ユ

Table 1 Details of samples

\begin{tabular}{|c|c|c|c|}
\hline $\begin{array}{c}\text { Sample } \\
\text { name }\end{array}$ & Material & $\begin{array}{c}\text { Diameter of } \\
\text { fiber }(\mu \mathrm{m})\end{array}$ & $\begin{array}{c}\text { Yarn counts } \\
(\mathrm{dtex})\end{array}$ \\
\hline Nylon 6 & Nylon 6 & 200 & - \\
\hline Procon & PPS & 20 & 250 \\
\hline DE-75 & Glass & 6 & 675 \\
\hline
\end{tabular}

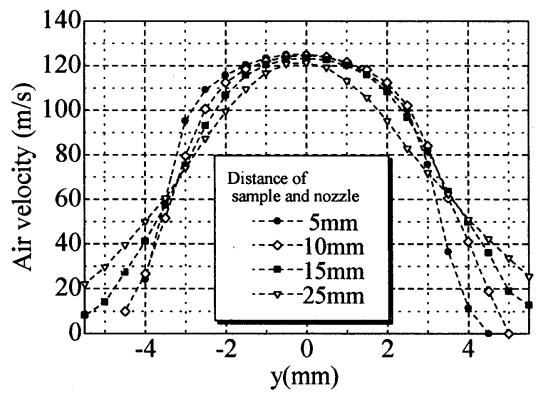

Fig. 3 The potential core domain (speed distribution) in collision distance in erosion system

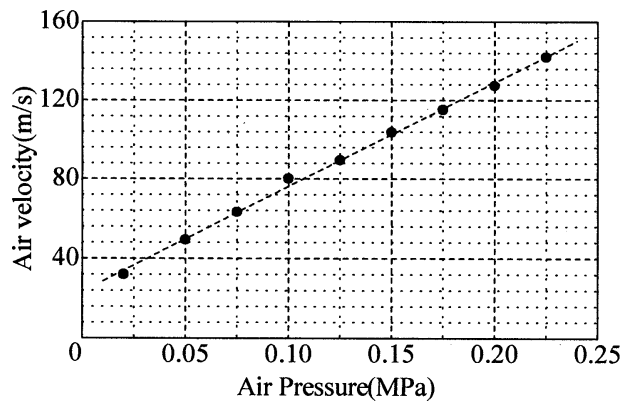

Fig. 4 Relation between air velocity and air pressure in air tank by measurement
ニチラグラスファイバー製の DE-75 繊維(ガラス繊 維)の 2 種類とした. 表 1 に 2 種類の繊維材料のデー 夕を示す. Procon と DE-75 は現在バグフィルタに使 用されている繊維である. また, エロージョン予備実 験として, 東レ製のやや太いナイロン 6 (直径が 0.2 $\mathrm{mm}$ )を用いて行った.

本実験で使用する粉体は, 白色アルミナ研削材 (Showa Denko K. K.) で, 平均粒径は $11.5 \mu \mathrm{m}$ で, 標 準偏差は $21.5 \mu \mathrm{m}$ である. 実際にごみ焼却場によっ て回収されたフライアッシュの径平均を参考にこれを 選択した。

図 5 はナイロン 6 の測定例である. 衝突角度は $90^{\circ}$ で, 粉体衝突速度は $127.4 \mathrm{~m} / \mathrm{s}$, 摩耗時間は $2 \mathrm{~min}$ で ある.引張実験の測定より, 図 5 のような Stressstrain 曲線が示される. 繊維の最大応力をとり, 破断 応力 (Breaking stress)とする. 各エロージョン時間 においても同様の実験を 5 回行い, 図 6 の摩耗時間破断応力曲線が作成できる. 横軸は摩耗時間で, 摩耗

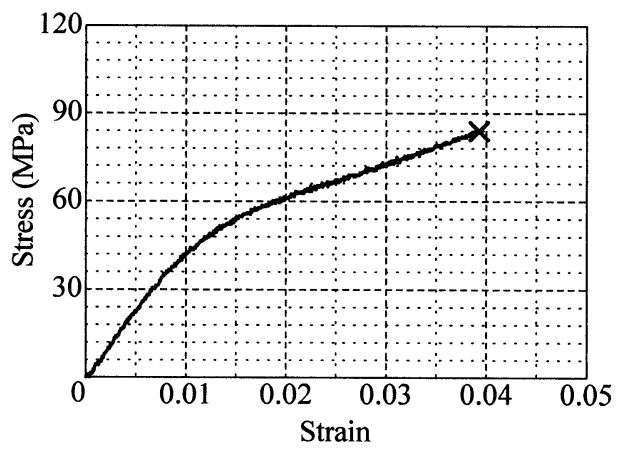

Fig. 5 Stress-strain curve of fibers after wear (Nylon 6, Impact angle : 90 degree, Wear : 2 min)

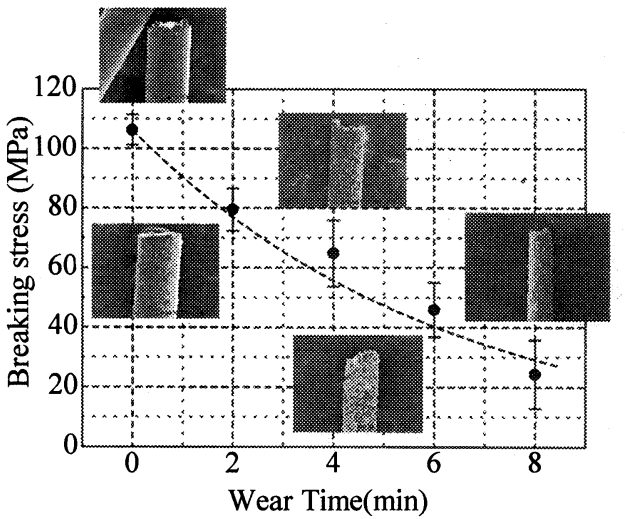

Fig. 6 Breaking stress-wear time curve of fibers (Nylon 6, Impact angle: 90 degree) 
時間が増えるに従って, 繊維の破断応力が低下してい る. SEM 写真によると, 摩耗時間が長くなると, 繊 維表面が摩耗されていて, エロージョンが実験的に再 現できている.

ごみ焼却施設のバグフィルタの繊維材料は, ダイオ キシンの発生などを考慮して, $190^{\circ} \mathrm{C}$ 以下の環境で使 用されている。このため高温環境での繊維のエロージ ヨン特性を調べる必要がある.ここで, 図 1 に示すホ ットエアビーム(HAB 4051, HAKKO Co. Ltd.) を利 用して, $300^{\circ} \mathrm{C}$ で噴射の空気を加熱できるようにし た. 図 7 はその部分の写真である.

\section{3. エロージョンの評価方法と考察}

$3 \cdot 1$ 粉体衝突角度による粉体重量 材料のエロ ージョンにおける摩耗量は単位面積当たりの衝突粉体 量と関連している. 粉体が繊維に衝突接触面積は衝突 角度 (Impact degree)によって図 8 に示したように変 化する. 単位面積当たりの衝突粉体総重量 $\left(W_{c}\right)$ は次 のようになる。

$$
W_{c}=\rho \cdot t / A \quad\left[\mathrm{~g} / \mathrm{m}^{2}\right]
$$

ただし $t$ が摩耗時間 $[\mathrm{s}], A$ が粉体真の接触面積 $\left[\mathrm{m}^{2}\right]$ (True contact area), $\rho$ が単位時間当たりのマ イクロフィーダから供給された粉体の重さ $[\mathrm{g} / \mathrm{s}]$ であ る.

図 9 は衝突粉体総重量と繊維の破断応力との関係で

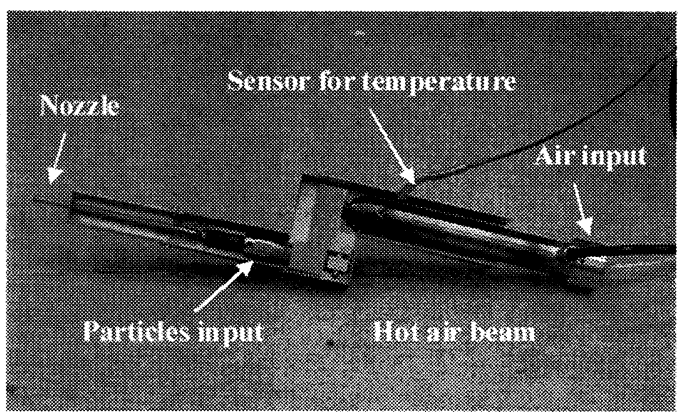

Fig. 7 The sketch map of hot air beam

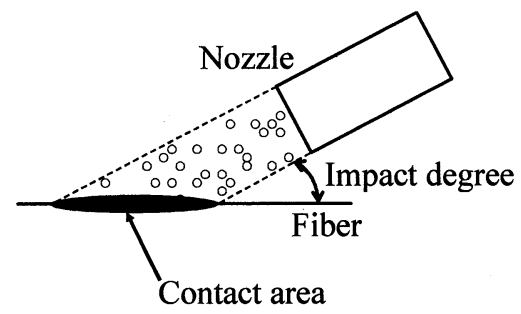

Fig. 8 True contact area $(A)$ of the particle
ある.サンプルは Procon 繊維で, 衝撃の角度は $15^{\circ}$, $30^{\circ}, 45^{\circ}, 60^{\circ}, 75^{\circ}, 90^{\circ}$, 衝突速度は $80.2 \mathrm{~m} / \mathrm{s}$ である. 図 9 に示したように, 衝突角度が $75^{\circ}, 90^{\circ}$ のものに比 べて, 角度が小さくなると, 纎維が急速に摩耗され, その破断応力が急に小さくなる.

$3 \cdot 2$ 粉体の運動エネルギーと材料の損傷率 材 料のエロージョン特性は粉体がサンプルに衝突する速 度に大きく影響している. 衝突速度が大きければ, 粉 体がサンプルに衝突する前の運動エネルギーが大きく なり, サンプルが摩耗されやすくなる，また，材料に よって, その影響と程度が変わると考えている.ここ で単位面積当たりの衝突粉体総重量から, 衝突する前 の粉体の運動エネルギーの和 $\left(W_{E}\right)$ は

$$
W_{E}=W_{c} V^{2} / 2 \times 10^{-3} \quad\left[\mathrm{~J} / \mathrm{m}^{2}\right] \cdots
$$

とする。ただし， $V$ は粉体の衝突速度 $[\mathrm{m} / \mathrm{s}]$ である。

また, 繊維の破断応力について, 異なる繊維のエロ ージョン特性を比較できるために, 損傷率(Damage) を次のように定義する。

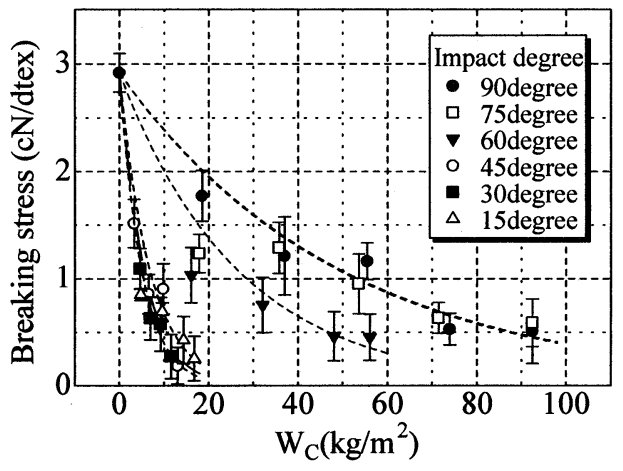

Fig. 9 Relation between particle mass per area of fiber and breaking stress for Procon

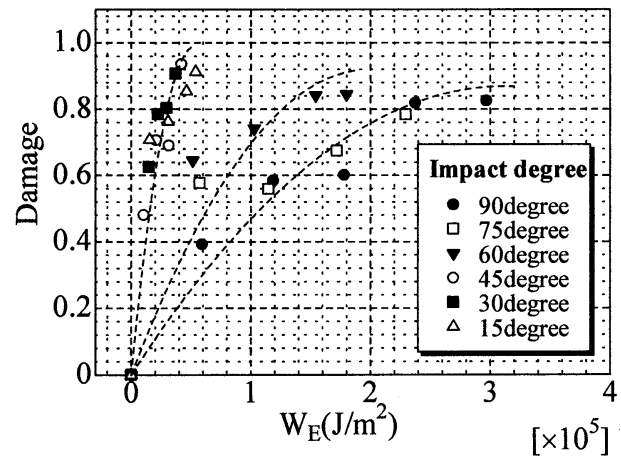

Fig. 10 Kinetic energy of impact-damage curve for Procon fibers 
Damage

$=\underline{\text { Breaking stress }}$ before $-{\text { Breaking } \text { stress }_{\mathrm{after}}}$ Breaking stress before

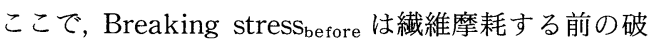

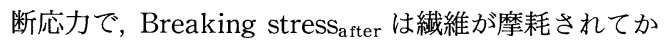
らの破断応力である. 図 10 は式 (2) と式 (3)を利用 して, 図 9 の結果を変換したものである。横軸は衝突 する前の粉体の運動エネルギーの和で, 縦軸は損傷率 である，この曲線で，繊維と繊維集合体がエロージョ ンによる材料の損傷状況と変化傾向が把握できる.

$3 \cdot 3$ 繊維とその集合体のエロージョン特性 繊 維材料とその集合体のエロージョン特性が図 10 のよ うな Damage- $W_{E}$ の表示方法で示すことができるが, いろいろな繊維と繊維集合体のエロージョン特性をわ かりやすく比べるために, 材料のある損傷率に至るま でに必要とする粉体の運動エネルギー和を用いて, 繊 維およびその集合体の耐エロージョン特性を評価す

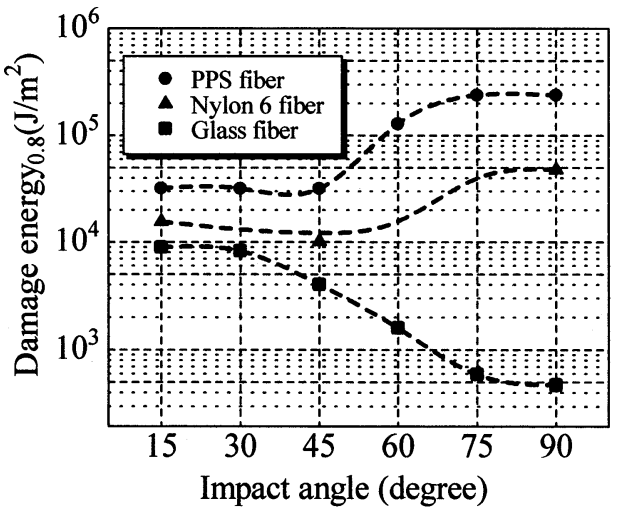

Fig. 11 Comparison of damage energy ${ }_{0.8}$ for fiber

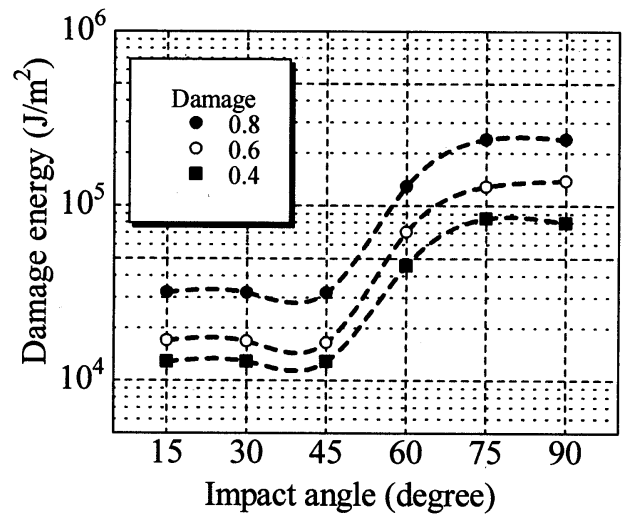

Fig. 12 Various damage energy of PPS fiber
る.ここで, サンプルの損傷率が 0.8 に至るまでに必 要とする粉体の運動エネルギーの和を 0.8 ダメージエ ネルギー (Damage energy $\left.\mathrm{y}_{0.8}, \mathrm{~J} / \mathrm{m}^{2}\right)$ とする. 図 11 は 図 10 のデータを利用して, 3 種類の繊維材料の 0.8 ダ メージエネルギーと衝撃角度の関係を示している.

印，印と口印はそれぞれ PPS 繊維，ナイロン 6 繊維 とガラス繊維の測定值である。図 11 でわかるように, サンプルの損傷率が 0.8 に至るまでに, PPS 繊維はガ ラス繊維より大きな粉体の運動エネルギーの和(Damage energy . $_{0.8}$ ) が必要で, 各衝撃角度ともにPPS 繊維 の耐エロージョン特性がガラス繊維よりかなり優れて いることを示している. 式 (2)で示したとおり, 粉体 の運動エネルギーの和に粉体の衝突速度, 単位面積の 粉体の量, 摩耗の時間などの要素が含まれているので, 図 11 の 0.8 ダメージエネルギー曲線より, それらの 影響程度を推測することができる.

また, 図 11 は繊維ごとのサンプルの損傷率が 0.8 に至るまでに必要となる粉体の運動エネルギーの和と 衝突角度の関係を示しているから, 粉体衝撃角度の影 響も明らかになった. 図 11 に示したようにPPS 繊維 は低角度より高角度 $\left(75^{\circ} 90^{\circ}\right)$ のほうが必要となる粉 体の運動エネルギーの和が大きく, 耐エロージョン特 性はよいことがわかった. ガラス繊維について, PPS 繊維と反対に高角度より低角度 $\left(15^{\circ} 30^{\circ}\right)$ のほうが必 要となる粉体の運動エネルギーの和が大きく, 耐エロ ージョン特性は良いことを示している。これらより， 材料のエロージョンタイプなどを示され，繊維材料の エロージョンメカニズムの究明に対して参考になる。 繊維材料におけるエロージョンのメカニズムの詳細解 析は次報で報告する。

図 12 はPPS 繊維の損傷率が 0.4, 0.6,0.8に至る までに必要となる粉体の運動エネルギーの和の曲線で

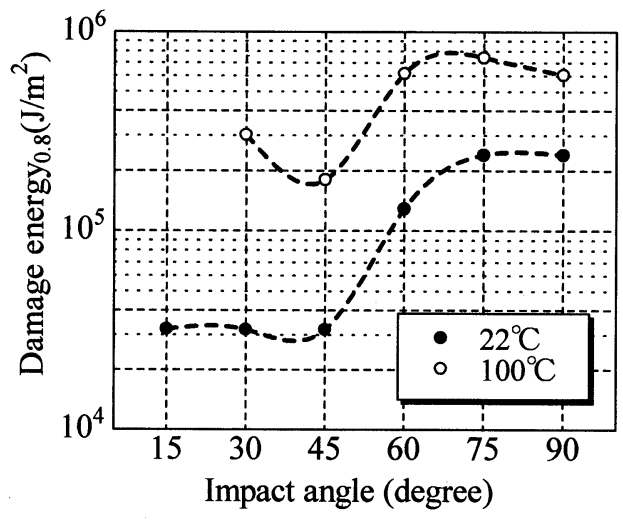

Fig. 13 Comparison of damage energy $y_{0.8}$ in temperature 
ある.図 12 に示したように, PPS 繊維のエロージョ ンは, 摩耗の初期で激しく,だんだん緩和されている. 繊維材料の各種ダメージエネルギー曲線を利用して, エロージョン特性が既知の繊維に対してその瀻維混紡 材料のエロージョン特性が予測できる。 また，今まで の予測できない繊維強化プラスチックのエロージョン 特性の予測に応用できると考えている。

図 13 はPPS 繊維に対して環境温度によるエロージ ヨン特性の変化を示している.これより, 高分子材料 の PPS 瀻維は適度の温度の上昇で, 耐エロージョン 特性も変わることがわかる。

\section{4. ま と め}

繊維材料とその集合体のドライサンド・エロージョ ン特性を把握するために, エロージョンによる引張破 断応力の低下程度を測定することにより材料のエロー ジョン評価法を提案した。

提案した評価法と試作した測定装置を利用して, 繊 維材料とその集合体のエロージョンの状態が再現で き，測定したサンプルの損傷率と衝突する前の粉体の 運動エネルギーとの関係から繊維材料エロージョンの 特性を把握できる。

それらをまとめたダメージエネルギー曲線は各種繊 維材料に対して粉体衝突角度, 衝突速度, 粉体供給量 が変化しても測定結果を比較することが可能となり, FRPのエロージョン特性の定量化にも応用できると 考える.

本研究に当たって, 有益な助言と協力をいただいた
日本スピンドル製造(株)の辻井澄生と木嶋敬昌にお礼 を申し上げる。

本研究は文部科学省科学研究費補助金 (COE 形成基 礎研究費：10 CE 2003）と［（C）（2）16560067］の補 助を受けて行った。

\section{文献}

(1) Hashimoto, K., Association of Powder Process Industry and Engineering Japan, Technology and Apparatus of Dust-Collection, (2001), pp. 87-99, NIKKAN KOGYO SHIMBUN, Ltd.

(2) Kishima, T. et al., Experimental study about particle wear of the bag filters, Society of Powder Technology of Japan Preprints, (2003), pp. 55-57.

(3) Hashimoto, K., Wear Resistance Designing of Particulate, Powder Science and Engineering, (1987), pp. 122128.

(4) Kimura, K. and Okabe, H., Introduction to Etiology, (1982), pp. 178-191, YOKENDO Inc.

(5) Schick, M. J., Surface characteristics of fibers and textiles, Part I, (1975), pp. 1-66, Marcel Dekker Inc., NY.

(6) Pool, K. V. et al., Erosive wear of composite materials, Wear, Vol. 107 (1986), pp. 1-12.

( 7 ) Harsha, A. P. et al., Solid particle erosion behaviour of various polyarylether- ketone composites, Wear, Vol. 254 (2003), pp. 693-712.

( 8 ) Häger, A. et al. (Street, K. and Whistler, B. C. eds.), Study of erosion wear of advanced polymer composites, Proceedings of the ICCM-10, (1995), pp. 155-162, Canada Woodhead Publishing Ltd., Cambridge.

(9) Barkoula, N. M. and Karger-Kocsis, J., Effects of fibre content and relative fibre-orientation on the solid particle erosion of GF/PP composites, Wear, Vol. 252 (2002), pp. 80-87. 